\title{
Suicide attempts and substance use in an emergency room sample
}

\author{
Tentativas de suicídio e o uso de substâncias \\ em uma amostra de pronto-socorro \\ Alessandra Diehl', Ronaldo Laranjeira'
}

\section{RESUMO}

Objetivo: Descrever as tentativas de suicídio atendidas em um pronto-socorro (PS) e o consumo agudo ou dependência de substâncias nestes indivíduos. Métodos: $\mathrm{O}$ estudo epidemiológico descritivo foi conduzido durante um ano para avaliação de tentativas de suicídio assistidas em um PS de Embu das Artes, SP. Os pacientes foram agendados para uma entrevista psiquiátrica não estruturada. As principais variáveis de desfecho foram: dados sociodemográficos, métodos da tentativa de suicídio, uso de álcool ou drogas seis horas antes da tentativa, pacientes com diagnóstico de dependência de substância pela CID-10. Utilizaram-se a análise descritiva e o teste qui-quadrado $(p<0,05)$ para verificar associações entre as diversas variáveis estudadas. Resultados: A amostra constituiu-se de 80 casos, cujos participantes tinham idade média de 26,9 anos ( $D P=8,91$ ), predominantemente de mulheres (72,5\%), 21,2\% de adolescentes. A maioria das tentativas de suicídio foi por ingesta de medicação (62,5\%). Aproximadamente $21,2 \%$ e 7,5\% relataram ter feito uso de álcool e de drogas ilícitas, respectivamente, nas seis horas que antecederam a tentativa

\section{Palavras-chave}

Tentativas de suicídio, desordens relacionadas ao uso de substâncias, ingestão de álcool, pronto-socorro. e 10\% da amostra têm dependência de substâncias. Todos os dependentes de substâncias já tentaram suicídio anteriormente $(p$-valor $=0,4)$. Houve associação significativa entre a forma da tentativa de suicídio por ingesta de medicação e histórico de tratamento psiquiátrico $(p=0,02)$. Conclusão: Mais estudos nacionais são necessários para considerar o papel do uso de álcool e drogas em tentativas de suicídio assistidas em PS, especialmente em dependentes químicos cujo comportamento suicida é relevante.

\begin{abstract}
Objective: Describe suicide attempts assisted in an emergency room (ER) and acute substance consumption or dependence on these individuals. Methods: Descriptive epidemiologic study was carried out during one year, evaluating suicide attempts assisted at Embu das Artes ER, São Paulo, Brazil. Patients were scheduled to a non structured psychiatric interview. Main outcomes measures were: socio demographic data, suicide attempt method, drugs or alcohol acute use in the six hours prior to attempt, patients with ICD-10 substance dependence diagnosis. The des-
\end{abstract}

1 Universidade Federal de São Paulo, Escola Paulista de Medicina (Unifesp/EPM), Departamento de Psiquiatria, Unidade de Pesquisa em Álcool e Drogas (Uniad). 


\section{Keywords}

Suicide attempt, substance related disorders, alcohol drinking, emergency service. criptive analyses and chi-square test $(p<0.05)$ were used to verify associations between the variables studied. Results: sample was formed of 80 patients, mean age of 26.9 years (SD $=8.91$ ), predominantly female $(72.5 \%)$ and $21.2 \%$ adolescents. Most suicide attempts were made through medicine ingestion (62.5\%). Approximately $21.2 \%$ and $7.5 \%$ related to have used alcohol and an illicit drug respectively within 6 hours prior to attempt and $10 \%$ were found to be substance dependent. All substance dependents had attempted suicide previously ( $p$-value $=0.4$ ). There was a significant association between suicide attempt through medicine ingestion and psychiatric treatment history $(p=0.02$ ). Conclusion: More national studies are necessary to consider the role of alcohol and drug in suicide attempts assisted in ER, especially in chemical dependents whose suicidal behavior is relevant.

\section{INTRODUCTION}

In many countries suicide attempt has been the target of great concern in the last decade $e^{1-3}$. In the global context, the most important finding when analyzing data is the observation that mean age of individuals who commit suicide is decreasing ${ }^{3,4}$ aggravated to the fact that substance use is intimately related to suicide behaviors ${ }^{5-7}$.

Drinking is strongly associated to suicidal thoughts and in women, this may occur with occasional drinking ${ }^{8-12}$. Studies, however, do not concur to whether the risk is higher due to abuse or the substance dependence ${ }^{6,10}$. Data from MACHT (Matching Alcoholism Treatments to Client Heterogeneity, 1997) revealed that suicidal thoughts are more prevalent among alcohol dependents in treatment ${ }^{7}$.

Cherpitel et al. ${ }^{13}$ reviewed literature on acute alcohol use and suicidal behavior in an adult population (1991-2001); and found 53 studies with a broad variety of positive alcohol cases related to suicide (10\% to 69\%) and to suicide attempts (10\% to $73 \%)$.

Studies have demonstrated drug users to have higher prevalence and an increased suicide attempt predisposition ${ }^{14-16}$.

In Brazil, general population data referring to suicide and suicide attempts in epidemiological researches are few, mainly due to failure in the notification of suicides and suicide attempts. Improper data quality contests the validity of official suicide mortality indexes. Consequently, epidemiological studies are imprecise 4 .

Additionally, there are few studies on substance related suicide attempts in Brazil. Some national studies available on this association have been carried out in different settings and results have shown a broad variety of prevalence, corroborating to the existence of an association ${ }^{17-21}$. Studies in specific populations as intravenous drug users, adolescents, pregnant adolescents and more recently, over the first National Research over Alcohol Consumption Behavior in the Indigenous Brazilian Population are also available ${ }^{22-26}$.

It is possible that a reduction in psychiatric morbidity may result in suicide risks decrease, specifically in persons who have previously attempted suicide, who suffered from major mood disorders, abuse or substance dependence, among others disorders ${ }^{2,27}$.

Data from suicide attempts and substance use in ER studies is very useful in health policy decision making, preventive and intervention plans in episodes related to this association ${ }^{28,29}$. The objective of this study is to describe suicide attempts assisted in emergency room (ER) setting and acute substance consumption or dependence on these individuals.

\section{METHODS}

\section{Setting}

Data analyzed was obtained from UMS Irmã Annete Marlene Emergency Room in Embu das Artes County of São Paulo, Brazil, from December 12, 2006 to December 12, 2007. This is a seven day a week, $24 \mathrm{hr}$ service. It provides ER services to adults and offers 20 beds to low complexity clinical cases and 5 psychiatric observation beds. This service provides approximately an average of 500 consultations per day. The medical team is composed of 34 emergency physicians, 54 nurse assistants and 7 nurses in shifts. There is another similar service profile ER located downtown Embu das Artes.

The city population of 228.616 inhabitants is predominantly of young adults aged 20 to 29 years (46.691 inhab.), 59\% of municipal district is located in a water protection area and the city ranks $26^{\text {th }}$ among the cities with highest mortality rate for external causes in the state of São Paulo. The main activity areas are flower cultivation, horticulture, apiculture, specialized antiquities trade, furniture, craft, art objects, focus on tourist market and other varied commercial activities ${ }^{30}$.

\section{Design}

A descriptive epidemiological study (transversal cohort) evaluating patients who attempted suicide assisted at the ER mentioned above. This study design was approved by the Universidade Federal de São Paulo Ethics Committee, 
protocol number 1410/07. All subjects signed an informed consent term and an authorization by the parents or legal guardians was requested for subjects under 18 years old.

All patients admitted in this ER routinely fill out an admission form (AF) which includes data such as: name, age, gender, race, address and telephone number. Daily all AF are sent to the administration office, where information is analyzed by two assistants. During epidemiological vigilance period the AF from those who attempted suicide was requested. Further, the team was trained and motivated to fill out the suicide attempt notification. To be considered a suicide attempt, the individual had to be aware that the action was a threat to his/her life ${ }^{17}$.

This measure of reporting suicide attempts cases was implemented in council services in 2002, aiming to refer all cases to a mental health team as soon as possible. Data provided by the Mental Health Program of Embu das Artes showed that during the year 2005 only 39 attempts were reported to the two municipality emergency rooms. Predominantly young females (64.1\%) 15 to 29 years $^{30}$.

Afterwards, nurses scheduled the patient to a nonstructured psychiatric evaluation at the outpatient clinic as soon as discharged from the ER.

ER reference network has three psychiatrists. The psychiatric evaluation main objective in this study was to identify the absence or the presence of disorders related to alcohol and/or other psychoactive substances. Since this screening in the ER not used routinely scales or standardized questionnaires to identify possible "problem drinkers" and the severity related to illegal substance use, for example. From a clinical perspective patients were referred to a psychiatric evaluation in an attempt to consolidate ER action routines. Furthermore, psychiatric evaluation intended to encourage early recognition necessity and proper treatment for depression, psychotic disorder, alcohol and drugs abuse, suggesting that improving mental illness diagnosis and treatment is an excellent suicide prevention strategy for general population 2,17,34.

When the patient was not scheduled or failed to appear to the psychiatric evaluation, telephone or telegram contact was attempted. When contact was still not possible, a request to the local health unit, closest to the patient house attempted domicile visit and consultation.

Data available in medical report, AF and or in the suicide attempt notification was used.

Main outcomes measures

1. Socio demographic data.

2. Suicide attempt method.

3. Self-report of alcohol or drugs use within six hours prior to attempt.

4. Patients with International Disease Classification (ICD10) diagnosis of alcohol or other drugs dependence.
According to ICD-10 operational criteria, the alcohol dependence syndrome comprises a group of cognitive behavioral and physiologic disturbs, in the last 12 months (craving, tolerance, withdrawal syndrome, reduction of the range of consumption despite harm to health/family, abandonment of pleasure). The presence of three or more symptoms in the period fills alcohol dependence diagnosis criteria. Otherwise it is diagnosed harmful behavior or abuse episode ${ }^{31}$.

5. Psychiatric treatment history.

\section{Statistical analysis}

The statistical analysis included variables descriptive and the chi-square test $(p<0.05)$ for contingency table, to verify associations between the variables in study ${ }^{32}$. The information collected was stored in database using the Statistical Package for Social Sciences (SPSS) software, version 10.0 (SPSS, Inc., Chicago, IL, USA). Social demographic variables were tested by chi-square: gender, age, marital status, religion, educational level, race and method used for suicide. All variables are categorical.

\section{RESULTS}

\section{Participants}

Sample was formed of 80 suicide attempt cases, being 36.2\% ( $n=29)$ did not attend the scheduled psychiatric interview.

From the sample group, $48.7 \%(n=39)$ patients had previously undergone psychiatric treatment. Table 1 demonstrates socio demographic profile sample, which was predominantly of youths with mean age $=26.9(S D=8.91$, minimum: 12 , maximum: 52$)$ and women in $72.5 \%(n=58)$.

Those 18 years of age or under were considered adolescents. In this sample, there were $21.2 \%(n=17)$ of adolescent suicide attempts. This sub sample was predominantly female (88.2\%) from those $88.3 \%$ single, $52.9 \%$ white and $47.7 \%$ attempted suicide through medicine ingestion followed by $41.2 \%$ self poisoning, $3.75 \%(n=3)$ had ingested alcohol within 6 hours prior the attempt, there was no report of illegal substance use. No previous psychiatric treatment was related among the adolescents.

\section{Suicide attempt}

The most common method for suicide attempt was through medicine ingestion in $62.5 \%(n=50)$, followed by self poisoning $30 \%(n=24)$, sharp objects $3.75 \%(n=3)$, hanging in $2.5 \%(n=2)$ and domestic alcohol ingestion in $1.25 \%$ $(n=1)$. Statistically significant association between method used to attempt suicide and socio demographic data evaluated was not found (Table 1). 
Table 1. Socio-demographic profile (Embu das Artes, 2007)

\begin{tabular}{|c|c|c|c|c|c|}
\hline \multirow[b]{2}{*}{ Characteristics } & \multirow[b]{2}{*}{$N(\%)$} & \multicolumn{3}{|c|}{ Method for suicide attempt } & \multirow[b]{2}{*}{ p-value } \\
\hline & & $\begin{array}{l}\text { Medicine } \\
\text { ingestion }\end{array}$ & $\begin{array}{c}\text { Self } \\
\text { poisoning }\end{array}$ & Others & \\
\hline \multicolumn{6}{|l|}{ Gender } \\
\hline Female & $58(72.5)$ & $39(67.2)$ & $15(25.9)$ & $4(6.9)$ & \\
\hline Male & $22(27.5)$ & $11(50.0)$ & $9(40.9)$ & $2(9.1)$ & 0.356 \\
\hline \multicolumn{6}{|l|}{ Age group } \\
\hline 18 or under yrs & $17(21.2)$ & $8(47.0)$ & $7(41.2)$ & $2(11.8)$ & \\
\hline 19 to $20 \mathrm{yrs}$ & $11(13.8)$ & $7(63.6)$ & $3(27.3)$ & $1(9.1)$ & \\
\hline 21 to $30 \mathrm{yrs}$ & $30(37.5)$ & $20(66.7)$ & $7(23.3)$ & $3(10.0)$ & \\
\hline 31 to 40 yrs & $14(17.5)$ & $12(85.7)$ & $2(14.3)$ & $0(0.0)$ & \\
\hline 41 or more yrs & $8(10.0)$ & $3(37.5)$ & $5(62.5)$ & $0(0.0)$ & 0.249 \\
\hline \multicolumn{6}{|l|}{ Marital status } \\
\hline Single & $27(33.8)$ & $13(48.2)$ & $11(40.7)$ & 3 (11.1) & \\
\hline Married & 19 (23.7) & $9(47.4)$ & $7(36.8)$ & $3(15.8)$ & \\
\hline Separated & $5(6.3)$ & $3(60.0)$ & $2(40.0)$ & $0(0.0)$ & 0.903 \\
\hline (missing) & $29(36.2)$ & & & & \\
\hline \multicolumn{6}{|l|}{ Religion } \\
\hline Catholic & $19(23.8)$ & $12(63.2)$ & $5(26.3)$ & $2(10.5)$ & \\
\hline Evangelical & $9(11.3)$ & $5(55.6)$ & $3(33.3)$ & $1(11.1)$ & \\
\hline Atheist & $5(6.2)$ & $3(60.0)$ & $1(20.0)$ & $1(20.0)$ & 0.965 \\
\hline (missing) & $47(58.7)$ & & & & \\
\hline \multicolumn{6}{|l|}{ Educational level } \\
\hline None & $2(2.5)$ & $0(0.0)$ & $2(100.0)$ & $0(0.0)$ & \\
\hline 1 to 8 yrs & $13(16.2)$ & $9(69.2)$ & $3(23.1)$ & $1(7.7)$ & \\
\hline 9 to 11 yrs & $20(25.0)$ & $11(55.0)$ & $5(25.0)$ & $4(20.0)$ & \\
\hline 12 yrs or more & $1(1.3)$ & $1(100.0)$ & $0(0.0)$ & $0(0.0)$ & 0.296 \\
\hline (missing) & $44(55.0)$ & & & & \\
\hline \multicolumn{6}{|l|}{ Race } \\
\hline White & $42(52.5)$ & $24(57.1)$ & $14(33.3)$ & $4(9.5)$ & \\
\hline Black & $5(6.2)$ & $4(80.0)$ & $1(20.0)$ & $0(0.0)$ & \\
\hline Other & $19(23.8)$ & $12(63.2)$ & $5(26.3)$ & $2(10.5)$ & 0.858 \\
\hline (missing) & $14(17.5)$ & & & & \\
\hline
\end{tabular}

Group differences were assessed with chi-squared tests $(p<0.05)$.

From the $30 \%$ who attempted through self poisoning, $70.8 \%$ used carbamate most popularly known in Brazil as "chumbinho". It is a pesticide used improperly to terminate mice. An illegal commercial product sold informally ${ }^{33}$.

Statistically significant association between suicide attempt method and psychiatric treatment history was found $(p=0.026)$. From the patients who had undergone psychiatric treatment, 59\% selected to attempt suicide through medicine ingestion. It was observed that from the patients who attempted suicide with medicine, $26 \%$ used more than one psychotropic drug.

\section{Acute alcohol and drug use in six hour prior to the suicide attempts}

It was observed that $21.2 \%(n=17)$ and $7.5 \%(n=6)$ related to have ingested alcohol and illicit drugs (marijuana and/or cocaine) respectively within the six hours prior to the suicide attempt. From those 17 individuals who made acute alcohol use, 52.9\% were women, 58.8\% between 21 and 40 years of age, $35.3 \%$ were married, $41.2 \%$ white, $52.9 \%$ ingested medicine as method of attempt and $23.5 \%$ had previously undergone psychiatric treatment. From the 17 subjects who ingested alcohol, 52.9\% ingested medicine to attempt suicide, $29.4 \%$ attempted suicide by poisoning and $17.7 \%$ chose other methods.

Statistically significant association between suicide attempt method and alcohol use within six hours prior to the event ( $p=0.346)$ or drug use ( $p=0.205$ ) was not found.

\section{Substance dependence}

Substance dependence was observed in 10\% of sample. All substance dependents had attempted suicide previously ( $p$-value $=0.204), 62.5 \%$ attempted suicide by medicine ingestion; while 1 subject attempted suicide by poisoning and 2 (25.0\%) chose other methods. There was no significant relationship between dependence on substance and type of suicide attempt ( $p$-value $=0,204)$.

\section{DISCUSSION}

Our sample is similar to those found in international literature regarding prevalence of women and young population attempting suicide through medicine ingestion ${ }^{2,9,11}$. As well as, acute alcohol ingestion before suicide attempt in $21.2 \%$ of the sample concurring with the results of other international studies reviewed by Cherpitel et al. ${ }^{13}$.

However, some aspects should be considered. Data reported may have been inaccurate due to lack of: standard questionnaire, information about alcohol intoxication in the AF, difficulties in interviewing all patients, absence of a breathalyzer test, blood alcohol concentration measure or screening drugs tests in ER study.

The authors are aware of the fact that results may have been affected by loss or incomplete data. However, we consider important to record this information, since international literature is really wide on this issue and there is a clear lack of national studies evaluating suicide attempt, acute alcohol use and/or illegal substances in ER. In Brazil, there in no ER public health policy for suicide attempts related to alcohol and drugs use. Although this association is well known, it is still poorly documented in our country, hence the need for more studies. Certainly, other study designs as case control for example, may add providing reliable information.

Regarding the research on illicit drug use based only on self reports tend to be usually underestimated. There is need for alternatives in the identification and detection strategies. Cost for urine screenings effectiveness remains questionable and unknown due to legal implications ${ }^{36}$.

In our sample a 12 year old attempted suicide. Suicide attempt studies in adolescent samples have shown this to be an adverse time in their life, since a suicide attempt makes them susceptible to other suicide attempts ${ }^{37}$.

In the adolescent's sample, the report of alcohol use within six hours prior suicide attempt was relatively low when compared to other national studies involving the same po- 
pulation. In a study carried out by Marcondes et al. on 70 suicide attempts among young people aged 12 to 24 treated at a university ER in the southern region of the country from January 1994 to July 1999 observed that: marijuana, cocaine and solvents had a use frequency of $29.5 \%, 11.1 \%$ and $14 \%$, respectively ${ }^{26}$.

Serfaty in a suicide attempt literature review observed that $10 \%$ of adolescents who had attempted suicide, did it again and succeeded within a period of 10 years from first attempt. Since they believed to be capable of resolving problems on their own, only $25 \%$ sought medical assistance. Therefore, it is fare to consider this to be satisfactory evidence to put forward preventive strategies to assist this specific population ${ }^{38}$.

In this study, data on suicide attempt has demonstrated that $62.5 \%$ ingested medicine in significant relation to previous medical treatment. Polypharmacy has been mentioned in studies as a severity indicator for some pathologies and associated to increase in suicide attempts ${ }^{39}$. According to the National System of Toxic-Pharmacological Information study (Sinitox) in 1993-1996, 44\% of all medicine poisonings in Brazil were classified as suicide attempts, and $62 \%$ were medicine related ${ }^{40}$. "Domestic pharmacy" and polypharmacy in patients with psychiatric disorders are possible targets for education and prevention.

The use of the popularly known "chumbinho", in most poisoning cases, is worth to mention. Since 1986 the Instituto Médico Legal (IML) has received fatal victims of poisoning by this "raticide". This is a commercial product, with no official records, sold illegally and informally. Since then there has been a rising wave of suicides, homicides and accidental poisoning by this product. In the stomach of the victims tiny granules were found, spherical, lead-gray in color and odorless. The toxicological analysis showed the material it is the carbamate insecticide Aldicarb. Subsequently, some organophosphates were detected with the Aldicarb or separately. According to data obtained in the IML-RJ in the years of 2000-2001-2002, the insecticide Aldicarb was responsible for over 300 deaths in Rio de Janeiro. It is necessary to alert the population to the risk and danger of this substance which is erroneously used to kill rats, and causes poisoning leading to death ${ }^{37,41}$.

In this sample, all substance dependents had previously tried suicide at least once ( $p$-value $=0.4$ ). Studies show that suicidal behavior is common in substance dependent subjects ${ }^{5,7,13}$ Impulsive and aggressive traits might contribute significantly to the risk of suicide attempts in this population, especially in users of injectable drugs ${ }^{29}$. Although it is known that subjects with substance related disorders deserve special attention in psychiatric care network to prevent suicide, there is no strong evidence of long term suicide rate reduction in risk populations, particularly in people with major affective disorders, alcohol and drug abuse history as primary condition or psychiatric comorbidities.
It is quite possible that the reduction of psychiatric morbidity should reduce the risk of suicide, but little is known about the specific effects of most psychiatric treatments or other interventions aimed at suicide prevention ${ }^{2,27}$.

\section{Limitations}

Incomplete data due to appointment attendance failure; underreport of suicide attempts and data collection regarding alcohol or drug involvement are among the main limitations in this research.

\section{Implications on future studies}

We suggest the development of different methods of research in order to better assess the alcohol role and drugs in suicide attempts, such as, case control studies ${ }^{42}$.

Moreover, we emphasize the strong need of continuous education, training and supervision of the professional team in ER, since suicide attempts are difficult to manage and report. Consequently generating sub-clinical recognition and improper report of important events. Therefore, organized efforts and actions are essential to establish better understanding and care for suicide attempt victims, designing effective programs to prevent suicidal behavior ${ }^{34}$.

\section{CONCLUSION}

More national studies are necessary to consider the role of alcohol and drug in suicide attempts assisted in ER, especially in chemical dependents whose suicidal behavior is relevant

\section{ACKNOWLEDGMENTS}

To all ER staff for their attention and cooperation in the conduction of this research, our sincere gratefulness and appreciation.

Universidade Federal de São Paulo (Unifesp), Escola Paulista de Medicina (EPM), Unidade de Pesquisa em Álcool e Drogas (Uniad).

\section{REFERENCES}

1. World Health Organization (WHO). Figures and facts about suicide. Geneve, 1999. The World Health Report 2003: shaping the future. Geneva, 2003.

2. Botega NJ, Raeli CB, Cais CFS. Comportamento suicida. In: Botega NJ. Prática psiquiátrica no hospital geral: interconsulta e emergência. 2a ed. Porto Alegre: Artmed; 2006. p. 431-46.

3. Bertolote JM, Fleishmann A. A global perspective in the epidemiology of suicide. Suicidologi. 2002:7(2):6-7.

4. Melo-Santos C, Bertolote JM, Wang YP. Epidemiology of suicide in Brazil (1980-2000): characterization of age and gender rates of suicide. Rev Bras Psiquiatr. 2005;27(2):131-4. 
5. Berglund $M, 0$ jehagen $A$. The influence of alcohol drinking and alcohol use disorders on psychiatric disorders and suicidal behavior. Alcohol Clin Exp Res. 1998;22(7 Suppl):333-45.

6. Borges $G$, Walters EE, Kessler RC. Associations of substance use, abuse, and dependence with subsequent suicidal behavior. Am J Epidemiol. 2000;51:781-9.

7. Conner KR, Li Y, Meldrum S, Duberstein PR, Conwell Y. The role of drinking in suicidal ideation: analyses of Project MATCH data. J Stud Alcohol. 2003;64(3):402-8.

8. Tondo L, Baldessarini RJ, Hennen J, Minnai GP, Salis P, Scanonatti L, Masia M, Ghiani C, Mannu P. Tentativas de suicídio no transtorno afetivo e comorbidade com abuso de drogas. J Clin Psychiatr. 1999;60(2):63-9.

9. Borges G, Angst J, Nock MK, Ruscio AM, Kessler RC. Risk factors for the incidence and persistence of suicide-related outcomes: a 10-year follow-up study using the National Comorbidity Surveys. J Affect Disord. 2008;105(1-3):25-33.

10. Borges G, Cherpitel CJ, MacDonald S, Giesbrecht N, Stockwell T, Wilcox HC. A case-crossover study of acute alcohol use and suicide attempt. J Stud Alcohol. 2004;65(6):708-14.

11. Wilsnack SC, Wilsnack RW, Kristjanson AF, Vogeltanz-Holm ND, Windle M. Alcohol use and suicidal behavior in women: Iongitudinal patterns in a U.S. national sample. Alcohol Clin Exp Res. 2004;28(5 Suppl):S38-47.

12. Borges $G$, Rosvsky H. Suicide attempts and alcohol consumption in an emergency room sample. J Stud Alcohol. 1996;57(5):543-8.

13. Cherpitel CJ, Borges GL, Wilcox HC. Acute alcohol use and suicidal behavior: a review of the literature. Alcohol Clin Exp Res. 2004;28(5 Suppl):18S-28.

14. Darke $S$, Kaye $S$. Attempted suicide among injecting and noninjecting cocaine users in Sydney, Australia. J Urban Health. 2004;81(3):505-15.

15. Havens JR, Strathdee SA, Fuller CM, Ikeda R, Friedman SR, Des Jarlais DC, et al. Collaborative Injection Drug User Study Group. Correlates of attempted suicide among young injection drug users in a multi-site cohort. Drug Alcohol Depend. 2004;75(3):261-9.

16. Garlow SJ, Purselle D, D'Orio B. Cocaine use disorders and suicidal ideation. Drug Alcohol Depend. 2003;170(1):101-4.

17. Botega NJ, Barros MB, Oliveira HB, Dalgalarrondo P, Marin-León L. Suicide behavior in the community: prevalence and factors associated to suicidal ideation. Rev Bras Psiquiatr. 2005;27(1):45-53.

18. Stefanello S, Cais CF, Mauro ML, Freitas GV, Botega NJ. Gender differences in suicide attempts: preliminary results of the multisite intervention study on suicidal behavior (SUPRE-MISS) from Campinas, Brazil. Rev Bras Psiquiatr. 2008;30(2):139-43.

19. Werneck, GL, Hasselmann MH, Phebo LB, et al. Tentativas de suicídio em um hospital geral no Rio de Janeiro, Brasil. Cad Saúde Pública. 2006;22(10):2201-6.

20. Schmitt R, Horn GH. Aspectos da interconsulta psiquiátrica em hospital de trauma. Rev Psiquiatr Rio Gd Sul. 2005;27(1):71-81.

21. Silveira DX, Jorge MR. Reports of attempted suicide among Brazilian addicts. Psychol Rep. 2004;95(1):71-4.

22. Malbergier A, De Andrade AG. Depressive disorders and suicide attempts in injecting drug users with and without HIV infection. AIDS Care. 2001;13(1):141-50.
23. Teixeira AMF, Luis MAV. Distúrbios psiquiátricos, tentativas de suicídio, lesões e envenenamento em adolescentes atendidos em uma unidade de emergência, Ribeirão Preto, São Paulo, 1988-1993. Cad Saúde Pública. 1997;13(3):517-25.

24. Marcondes Filho W, Mezzaroba L, Turini CA, Koike A, Motomatsu A, Shibayama EM, et al. Tentativas de suicídio por substâncias químicas na adolescência e juventude. Adolesc Latinoam. 2002;3(2).

25. Freitas GV, Cais CF, Stefanello S, Botega NJ. Psychosocial conditions and suicidal behavior in pregnant teenagers: A case-control study in Brazil. Eur Child Adolesc Psychiatry. 2008. [Epub ahead of print]

26. I Levantamento Nacional sobre os Padrões do Consumo de Álcool na População Brasileira. Levantamento Nacional de Uso de Álcool e Outras Drogas entre Populações Indígenas. Secretaria Nacional Antidrogas (SENAD), Brasília-DF; 2007.

27. Sher L. Alcohol and suicide: neurobiological and clinical aspects. Scientific World Journal. 2006;21(6):700-6.

28. Borges G, Saltijeral MT, Bimbela A, Mondragón L. Suicide attempts in a sample of patients from a general hospital. Arch Med Res. 2000;31(4):366-72.

29. Cherpitel ( J. Alcohol and injuries: a review of international emergency room studies since 1995. Drug Alcohol Rev. 2007;26(2):201-14.

30. Prefeitura do Município de Embu das Artes [acesso em 2008 May 24]. Disponível em: http://www.embu.sp.gov.br/.

31. Classificação de Transtornos Mentais e de Comportamento da CID-10. Descrições clínicas e diretrizes diagnósticas. Porto Alegre: Artes Médicas; 1993.

32. Bussab WO, Morettin PB. Estatística básica. 4a ed. São Paulo: Atual; 1993.

33. Machemer LH, Pickel M. Carbamates insecticides. Toxicology. 1994;91:29-36.

34. Botega NJ. Suicídio: saindo da sombra em direção a um Plano Nacional de Prevenção. Rev Bras Psiquiatr. 2007;29(1):7-8.

35. Reis AD, Figlie NB, Laranjeira R. Prevalência do uso de substâncias em pacientes com traumas em um pronto-socorro brasileiro. Rev Bras Psiquiatr. 2006;28(3):191-5.

36. Bast RP, Helmer SD, Henson SR, Rogers MA, Shafiro WM, Smith RS. Limited utility of routine drug screening in trauma patients. South Med J. 2000;93(4):397-400.

37. Avanci RC. 0 adolescente que tenta suicídio. Estudo Epidemiológico em uma Unidade de Emergência [dissertação de mestrado]. Ribeirão Preto, SP: Universidade de São Paulo; 2004.

38. Serfaty E. Suicídio na adolescência. Adolesc Latinoam. 1998;1(2):105-10.

39. Gazalle FK, Hallal PC, Tramontina J, Rosa AR, Adreazza AC, Zanatto V, et al. Polypharmacy and suicide attempts in bipolar disorder. Rev Bras Psiquiatr. 2007;29(1):35-8.

40. Bortoletto ME, Bochner R. Impacto dos medicamentos nas intoxicações humanas no Brasil. Cad Saúde Pública. 1999;15(4):859-69.

41. Lima RK, Spinelli E. Análise por cromatografia em camada delgada do inseticida carbamato Aldicarb em material post mortem. 1996;172:528-30.

42. Minayo MCS, Cavalcante FG, Souza ERS. Methodological proposal for studying suicide as a complex phenomenon. Cad Saúde Pública. 2006;22(8):1587-96. 